\title{
Anatomical and volatile components investigations on Primula vulgaris Huds. subsp. vulgaris (Primulaceae)
}

\section{Merve Has, Sevim Kucuk ${ }^{\star}$ and Mine Kurkcuoglu*}

Department of Pharmaceutical Botany, Faculty of Pharmacy, Anadolu University, Eskisehir-26470, Turkey *Department of Pharmacognosy, Faculty of Pharmacy, Anadolu University, Eskisehir-26470, Turkey

\section{Article Info}

\section{Article history}

Received 9 October 2021

Revised 29 November 2021

Accepted 30 November 2021

Published Online 30 December 2021

\section{Keywords}

Primulaceae

Primula

Anatomical

HS-SPME

GC/MS

\section{Introduction}

Primula L., one of the important genera of the Primulaceae family, is distributed in the world with about 426 species (Fico et al., 2007). Primula genus consists of 9 species, 2 of which are endemic and is known as "Cuhacicegi" in Turkey (Coskuncelebi, 2012). Some species of the family are used for ornamental plants (Simpson, 2012). The HMPC states that Primula veris and P. elatior (Primulaeradix) are used expectorant (EMA, 2016). Primula veris contain saponin glycosides, essential oil, flavone derivatives and especially used as expectorant. Evliya Celebi, in his book of "Seyahatname", refers to the good smell of Primula species and the plant's use in the treatment of eye diseases (Baytop, 1999). Many ethnobotanical studies have shown that $P$. vulgaris are used in different form and in the treatment of different target diseases (Jaric et al., 2007; Ugulu et al., 2009; Koca and Yildirimli, 2010; Saric Kundalic et al., 2010; Sarac et al., 2013; Akbulut and Ozkan, 2014).

In the literature, anatomical studies (Belaeva and Butenkova, 2019; Ergen-Akcin et al., 2019; Ergen-Akcin et al., 2021) and volatile components studies (Vitalini et al., 2011; Colombo et al., 2014) on Primula species have been reported. Primula vulgaris subsp. vulgaris (Primula acaulis (L.) Hill subsp. acaulis) is one of the 13 taxon of Primula genus in Turkey (Coskuncelebi, 2012) and flowers of this species are usually yellow, rarely white (Lamond, 1978). This study investigated the anatomical features and volatile components of $P$. vulgaris subsp. vulgaris.

Corresponding author: Dr. Sevim Kucuk
Professor, Department of Pharmaceutical Botany, Faculty of Pharmacy,
Anadolu University, Eskisehir-26470, Turkey
E-mail: salan@ anadolu.edu.tr
Tel.: +90-5452997214
Copyright (c) 2021 Ukaaz Publications. All rights reserved.

Email: ukaaz@yahoo.com; Website: www.ukaazpublications.com

\section{Materials and Methods}

\subsection{Plant material}

P. vulgaris subsp. vulgaris was collected during to flowering stage in 2018, Eskisehir. The specimen had been stored in Anadolu University, Faculty of Pharmacy Herbarium (ESSE:15532).

\subsection{Morphological and anatomical methods}

Plant specimen identification was made by using "Flora of Turkey" (Lamond, 1978). From a part of the material, 70\% alcohol sample was prepared for the anatomical study. In anatomical study, cross (root, pedicel, leaf) and superficial (leaf) sections were taken from plant parts. The section photos were taken using a light microscope (Olympus BX51T).

2.3 Headspace-solid phase microextraction (HS-SPME) procedure, gas chromatography/mass spectrometry analysis (GC/MS) and identification of components

SPME fibre precoated with a $75 \mu \mathrm{m}$ layer of Carboxen $($ / Polydimethylsiloxane (CAR/PDMS) (supplied by Supelco Bellefonte, USA), was used with a sampling time of $30 \mathrm{~min}$ (room temperature). The crushed rhizome and root volatile components of $P$. vulgaris subsp. vulgaris were captured with HS-SPME fiber and analyzed by GC/MS (Kucuk et al., 2018).

\section{Results}

\subsection{Anatomical results}

Primary growth is observed in cross sections taken from $P$. vulgaris subsp. vulgaris root. Epidermis is made up of a single layer, small and elliptic or round cells. The exodermis layer consists of 1-3 cells. The cortex layer covers a large area and consists of 16-18 rows of thick-walled parenchyma cells. Endodermis layer and 
pericycle can be distinguished. The xylem 8-arm (octa arch) or xylem arms can be very close to each other (Figure 1).

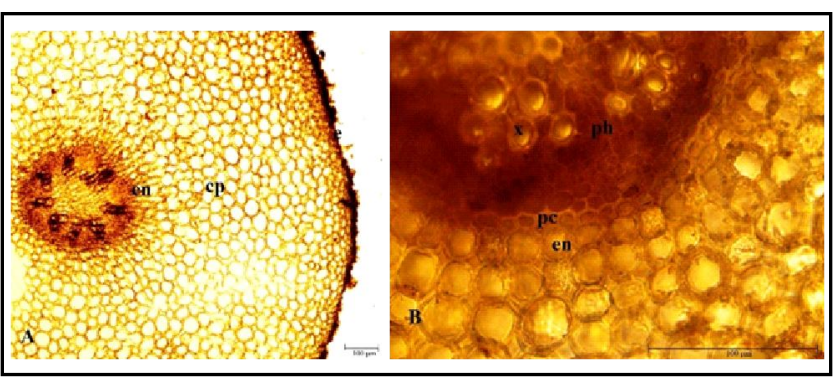

Figure 1: P. vulgaris subsp. vulgaris; cross-section of root. A: Schematic, B: Anatomic (e: epidermis, cp: cortex parenchyma, en: endodermis, pc: pericycle, $x$ : xylem, ph: phloem).

The outer part of the pedicel is consists of a corrugation cuticle layer and then a single row of small round or oval epidermis cells. The cortex layer is formed collenchyma and parenchyma cells. Under the epidermis layer, there are 3-4 lines of rarely intercellular spaces with collenchyma cells and then 3-4 rows of generally round parenchyma cells in areas near the central cylinder. There are phloem cells between the xylem arms lined in 5 rows (Figure 2).

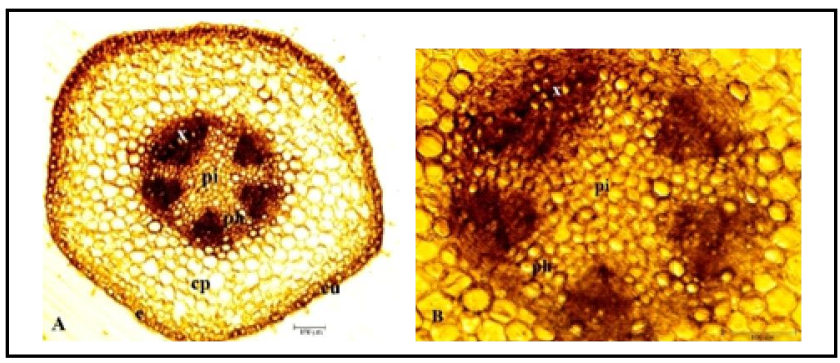

Figure 2: P. vulgaris subsp. vulgaris; cross-section of pedicel. A Schematic, B: Anatomic (cu: cuticula, e: epidermis, cp: cortex parenchyma, $x$ : $x y l e m, p h:$ phloem, pi: pith).

The following structures are observed in the leaf middle vein, leaf upper and lower superficial sections. The midrib of the leaf is schematically triangular. A row of small epidermis cells is located on the upper and lower surface of the leaf. Mesophyll layer consists of 1-2 rows of palisade parenchyma and 2-3 rows of sponge parenchyma (dorsiventral) (Figure 3).

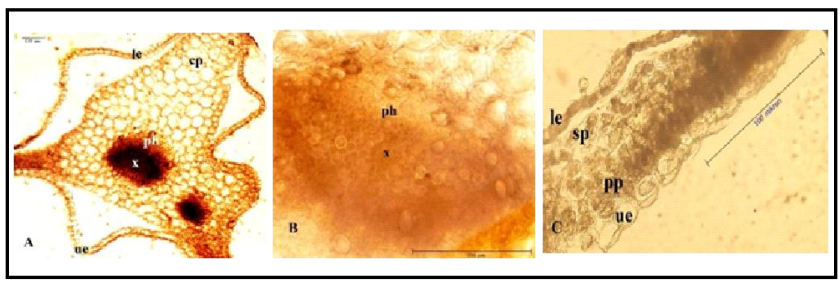

Figure 3: P. vulgaris subsp. vulgaris; cross-section of leaf. A: Schematic, B-C: Anatomic (ue: upper epidermis, le: lower epidermis, ph: phloem, x: xylem, sp: sponge parenchyma, pp: palisade parenchyma).

Stoma cells are observed on both surfaces of leaf superficial sections. The stoma on both its upper and lower surfaces is of an anomocytic type and has an oval or round shape. It is seen that lower epidermis cells are more corrugated than upper epidermis cells in superficial sections (Figure 4).

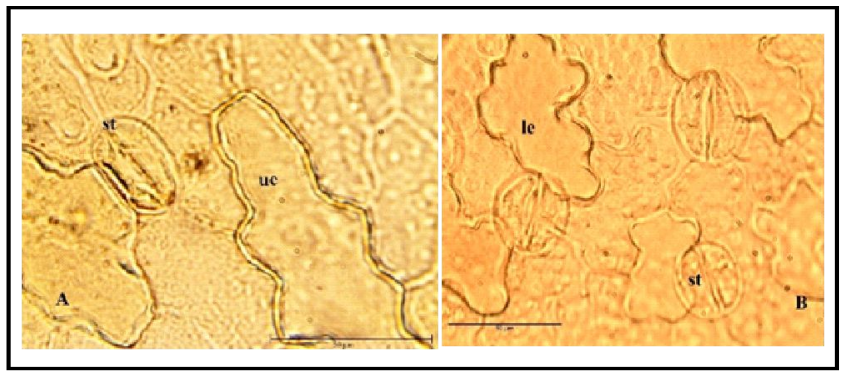

Figure 4: $P$. vulgaris subsp. vulgaris; leaf surface view of upper (A) and lower (B) (ue: upper epidermis, le: lower epidermis, st: stomata).

Glandular hairs are observed in the cross sections of the leaf and pedicel. Non-glandular hairs were not observed in the sections taken. In addition, glandular hairs have a single head cell and usually a single stalk cell (Figure 5).

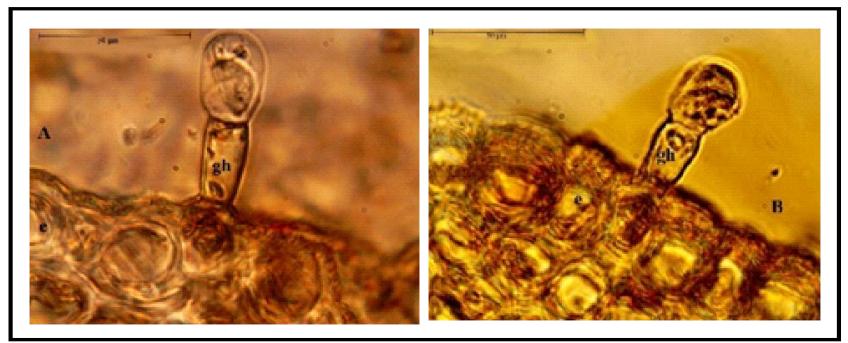

Figure 5: P. vulgaris subsp. vulgaris; hairs of leaf (A) and pedicel (B).(e: epidermis, gh: glandular hair).

\subsection{SPME results}

Volatile components of $P$. vulgaris subsp. vulgaris fresh and crushed underground parts were captured by HS-SPME technique and analyzed by GC/MS. The results are given in Table 1 .

Table 1: Volatile components of $P$. vulgaris subsp. vulgaris

\begin{tabular}{|c|l|c|r|}
\hline RRI & Compounds & $\%$ & ID \\
\hline 1203 & Limonene & 1.9 & $\mathrm{t}_{\mathrm{R}}, \mathrm{MS}$ \\
1255 & -Terpinene & 0.2 & $\mathrm{t}_{\mathrm{R}}, \mathrm{MS}$ \\
1265 & 3-Octanone & 2.3 & $\mathrm{t}_{\mathrm{R}}, \mathrm{MS}$ \\
1280 & p-Cymene & 5.5 & $\mathrm{t}_{\mathrm{R}}, \mathrm{MS}$ \\
1412 & 1,2-Dichloro benzene & 1.7 & $\mathrm{MS}$ \\
1495 & 2-Ethyl hexanol & 0.2 & $\mathrm{MS}$ \\
1532 & Camphor & 0.2 & $\mathrm{t}_{\mathrm{R}}, \mathrm{MS}$ \\
1541 & Benzaldehyde & 0.2 & $\mathrm{MS}$ \\
1611 & Terpinen-4-ol & 1.9 & $\mathrm{t}_{\mathrm{R}}, \mathrm{MS}$ \\
1637 & 1,2-Dichloro octane & 0.1 & $\mathrm{MS}$ \\
1798 & Methyl salicylate & 51.2 & $\mathrm{MS}$ \\
1878 & Guaiacol & 0.9 & $\mathrm{t}_{\mathrm{R}}, \mathrm{MS}$ \\
2219 & Methyl-4-methoxy salicylate & 18.5 & $\mathrm{MS}$ \\
2255 & Paeonol & 12.4 & $\mathrm{MS}$ \\
\hline
\end{tabular}


RRI: Relative retention in dices calculated against n-alkanes. Identification method (ID): MS, identified on the basis of computer matching of the mass spectra with those of the Wiley, Adams and Mass Finder libraries and comparison with literature data. $t_{R}$ : identification based on the retention times of genuine components on the HP Innowax column.

\section{Discussion}

In this study, the anatomical features of the $P$. vulgaris subsp. vulgaris collected from Eskisehir have been investigated with the sections taken from the root, pedicel and leaf parts.

Luna et al. (2017), in the leaf anatomical study of 5 genera and 33 taxa belonging to the Primulaceae family, were stated that a row epidermis layer and dorsiventral mesophyll are common features. Belaeva and Butenkova (2019) reported that Primula denticulata Sm., P. macrocalyx Bunge and $P$. pallasii Lehm. have anomocytic stoma type.

Ergen-Akcin et al. (2021) reported that in P. acaulis subsp. rubra, the root is xylem penta arch, the mesophyll layer in the leaf consists of 1-2 layers of palisade parenchyma, 2-3 layers of sponge parenchyma and stoma type is anomocytic stomata on both surfaces.

The anatomy of the P. acaulis subsp. acaulis was previously examined using the samples collected from Ordu province. In this study, it was reported that the pericycle layer in the root was evident, xylem tetra arch and the stomata in the leaf surface sections were of an anomocytic type (Ergen-Akcin et al., 2019). Unlike this study, root xylem was different and non-glandular hairs were not found in the leaf and pedicel sections in our study.

Fourteen volatile components were identified of the crushed rhizome and root representing $97.2 \%$ of $P$. vulgaris subsp. vulgaris. Main components were found as methylsalicylate (51.2\%), methyl-4methoxy salicylate $(18.5 \%)$ and paeonol $(12.4 \%)$.

Colombo et al. (2014) reported that a high amount of paeonal (98.0\%) was found in Primula albenensis Banfi and Ferl leaves. Involatile components or essential oil studies on Dionysia diapensifolia Boiss. (Primulaceae) and some Primula species, methylacetate or methyl-4-methoxy salicylate components were found (Javidnia et al., 2010; Vitalini et al. 2011; Yayliet al., 2016)

According to Yayli et al. (2016) reported that the ratios of methyl4-methoxy salicylate and (Z, Z, Z)-7,10,13-hexadecatrienal components in essential oils of $P$. vulgaris subsp. vulgaris and $P$. vulgaris subsp. sibthorpii collected from different altitudes varied significantly. Methyl-4-methoxy salicylate was one of main components in our study.

\section{Conclusion}

In this study, the anatomical features of the $P$. vulgaris subsp. vulgaris collected from Eskisehir have been investigated with the sections taken from the root, pedicel and leaf parts. Only glandular hairs were seen in the cross sections taken from the leaf and pedicel parts. It was observed that the leaf was amphistomatic and the stoma type was anomocytic on both surfaces. As a result, anatomical properties of $P$. vulgaris subsp. vulgaris are parallel within the literature studies. Regarding $P$. vulgaris subsp. vulgaris, 14 compounds have been identified in the rhizome and root. These are monoterpene $(7.6 \%)$, oxygenated monoterpene $(2.1 \%)$ and others $(87.5 \%)$.

\section{Conflict of interest}

The authors declare no conflicts of interest relevant to this article.

\section{References}

Akbulut, S. and Ozkan, Z.C.(2014). Traditional usage of some wild plants in Trabzon Region (Turkey). Kastamonu Univ., Journal of Forestry Faculty 14(1):135-145

Baytop, T. (1999). Therapy with medicinal plants in Turkey, past and present. (2nd ed.) Nobel Tip Press., Istanbul, Turkey, pp:192.

Belaeva, T.N. and Butenkova, A.N. (2019). Leaf anatomy of valuable species of genus Primula. Ukrainian. Journal of Ecology, 9(3):150-155.

Colombo, P.S.;Flamini, G.; Christodoulou, M.S.; Rodondi, G.;Vitalini, S.; Passarella, D. and Fico, G.(2014). Farinose alpine Primula species: Phytochemical and morphological investigations. Phytochemistry, 98:151-159

Coskuncelebi, K. (2012). List of the Flora of Turkey- Vascular Plants. In: Primulaceae. Guner, A.; Aslan, S.;Ekim, T.;Vural, M.andBabac, M.T.(Eds). Publication of Nezahat Gokyigit Botanical Garden and Flora Research Foundation, pp:770-771.

European Medicines Agency (EMA). (2016). Primulae radix (Primula root). (https://www.ema.europa.eu/en/medicines/herbal/primulae-radix 04.12.2021).

Ergen-Akcin, O.; Yapar, D. and Ozbucak, T. (2019). Anatomical properties of Primulaacaulis subsp. acaulis (Primulaceae) taxa distributed in Ordu vicinity. 3rd International UNIDOKAP Black Sea Symposium "Sustainable Agriculture and Environment", pp:113-118.

Ergen-Akcin, O.; Yapar, D.; Ozbucak, T. and Akcin, Y. (2021). An anatomical study on the Primulaacaulis subsp. rubra (Primulaceae) subspecies in the Middle Black Sea region. Akademik Ziraat Dergisi 10(1):195200 .

Fico, G.;Rodondi, G.;Flamini, G.; Passarella, D. and Tome, F.(2007). Comparative phytochemical and morphological analyses of three Italian Primula species. Phytochemistry, 68:1683-1691.

Jaric, S.; Popovic, Z.;Macukanovic-Jocic M.;Djurdjevic,L.;Mijatovic, L.; Karadzic, B.; Mitrovic, M. and Pavlovic, P. (2007). An ethnobotanical study on the usage of wild medicinal herbs from Kopaonik Mountain (Central Serbia). Journal of Etnopharmacology, 111:160-175.

Javidnia, K.; Miri, R.; Soltani, M. and Khosravi, A.R. (2010). Volatile oil of Dionysia diapensifolia Boiss. (Primulaceae) as a rich source of (E)-chalcone. Journal of Essential Oil Research, 22(5):386-388.

Koca, A.D. and Yildirimli, S.(2010). Ethnobotanical properties of Akcakocadistrict in Düzce (Turkey). Hacettepe J. Biol. and Chem., 38(1):63-69

Kucuk, S.; Kurkcuoglu, M. and Tuyan, C.S. (2018). Headspace volatiles of Allium subhirsutum L. growing in Turkey. Ann. Phytomed., 7(2): 180-182.

Lamond, J. (1978). Flora of Turkey and the East Aegean Islands.In: Primula L. (Primulaceae). Davis PH (Eds), Edinburgh: Edinburgh University Press, 6:112-115.

Luna, B.N.; Freitas, M.F.; Baas, P.; Toni, K.L.G. and Barros C.F. (2017). Leaf anatomy of five neotropical genera of Primulaceae. Int. J. Plant Sci., 178:362-377.

Sarac, D.U.;Ozkan, Z.C. andAkbulut, S.(2013). Ethnobotanic features of Rize/ Turkey province. Biological Diversity and Conservation, 6(3):5766. 
Saric-Kundalic, B.;Dobes, C.;Klatte-Asselmeyer, V. and Saukel, J.(2010) Ethnobotanical study on medicinal use of wild and cultivated plants in middle, south and west Bosnia and Herzegovina. Journal of Etnopharmacology, 131:33-55.

Simpson, M.G. (2012). Plant Systematics. Aytac. Z. (Trans. Eds.). Nobel Press, pp:383.

Vitalini, S.;Flamini, G.;Valaguzza, A.;Rodondi, G.;Iriti, M. and Fico, G. (2011). Primula spectabilis Tratt. aerial parts: Morphology, volatile compounds and flavonoids. Phytochemistry, 72:1371-1378.
Ugulu, I.;Baslar, S.;Yorek, N. and Dogan, Y.(2009). The investigation and quantitative ethnobotanical evaluation of medicinal plants used around Izmir province, Turkey. Journal of Medicinal Plants Research, 3(5):345-367.

Yayli, N.;Tosun, G.; Yayli, B.; Gundogan, Z.;Coskuncelebi, K. and Alpay-Karaoglu, S. (2016). Altitude variation in the composition of essential oils, fatty acid methyl esters, and antimicrobial activities of two subspecies of Primula vulgaris grown in Turkey. Natural Product Communications, 11(10):1505-1510. 